\title{
Role of woody biochar and fungal-bacterial co-inoculation on enzyme activity and metal immobilization in serpentine soil
}

\author{
Tharanga Bandara $^{1}$ - Indika Herath ${ }^{1} \cdot$ Prasanna Kumarathilaka $^{1}$. \\ Mihiri Seneviratne $^{2}$ - Gamini Seneviratne ${ }^{2}$ Nishanta Rajakaruna ${ }^{3,4}$. \\ Meththika Vithanage ${ }^{1}$. Yong Sik $\mathrm{Ok}^{5}$
}

\begin{abstract}
Purpose In this study, we investigated the effect of biochar (BC) and fungal bacterial co-inoculation (FB) on soil enzymatic activity and immobilization of heavy metals in serpentine soil in Sri Lanka.

Materials and methods A pot experiment was conducted with tomatoes (Lycopersicon esculentum L.) at 1, 2.5, and $5 \%(w /$ w) $\mathrm{BC}$ ratios. Polyphenol oxidase, catalase and dehydrogenase activities were determined by idometric, potassium permanganate oxidisable, and spectrophotometric methods, respectively. Heavy metal concentrations were assessed by $0.01 \mathrm{M} \mathrm{CaCl}_{2}$ and sequential extraction methods.

Results and discussion An increase in BC application reduced polyphenol oxidase, dehydrogenase, and catalase activity. The application of FB increased soil dehydrogenase activity, with the maximum activity found in $1 \% \mathrm{BC} 700+\mathrm{FB}$ treatment. Moreover, the $\mathrm{CaCl}_{2}$ extractable metals $(\mathrm{Ni}, \mathrm{Mn}$, and $\mathrm{Cr}$ ) in $5 \%$ BC700 amended soil decreased by 92,94 , and $100 \%$, respectively, compared to the control. Sequential extraction
\end{abstract}

Responsible editor: Jizheng He

Meththika Vithanage

meththikavithanage@gmail.com

1 Chemical and Environmental Systems Modeling Research Group, National Institute of Fundamental Studies, Kandy 20000, Sri Lanka

2 Microbial Biotechnology Unit, National Institute of Fundamental Studies, Kandy 20000, Sri Lanka

3 College of the Atlantic, Bar Harbor, ME, USA

4 Unit for Environmental Sciences and Management, North-West University, Potchefstroom 2520, South Africa

5 Korea Biochar Research Center and Department of Biological Environment, Kangwon National University, Chuncheon 200-701, Korea showed that the exchangeable concentrations of $\mathrm{Ni}, \mathrm{Mn}$, and Cr decreased by 55,70 , and $80 \%$ in $5 \%$ BC700, respectively. Conclusions Results suggest that the addition of $\mathrm{BC}$ to serpentine soil immobilizes heavy metals and decreases soil enzymatic activities. The addition of FB to serpentine soil improves plant growth by mitigating heavy metal toxicity and enhancing soil enzymatic activities.

Keywords Biochar · Bioremediation · Black carbon . Charcoal $\cdot$ Phytotoxicity

\section{Introduction}

Soils may be naturally rich in heavy metals or contaminated through anthropogenic activities (Neilson and Rajakaruna 2015). Unlike organic pollutants, heavy metals can persist in soil for extended periods, contributing to metal transfer through trophic levels (Gall et al. 2015). Serpentine is a naturally heavy-metal-rich soil with low concentrations of plant nutrients (Rajapaksha et al. 2012; Vithanage et al. 2014), including nitrogen $(\mathrm{N})$, phosphorus $(\mathrm{P})$, and potassium $(\mathrm{K})$. These soils are especially rich in chromium $(\mathrm{Cr})$, cobalt (Co), and nickel (Ni); the release of these metals into groundwater can have a negative impact on environmental and public health (Rajapaksha et al. 2013; Vithanage et al. 2014). The presence of excessive metal concentrations can also have grave consequences for agricultural productivity in the form of phytotoxicity and metal accumulation in crops (Baugé et al. 2013; Kayama et al. 2002; Susaya et al. 2010). As areas adjacent to serpentine outcrops are often used in agriculture (Vithanage et al. 2014), especially in developing countries, it is essential to develop environmentally-friendly methods to reduce phytoxicity and enhance crop productivity. 
Conventional soil remediation techniques contribute to environmental degradation and are not economically feasible on a large scale (Tica et al. 2011; Houben et al. 2013b), especially in developing countries (Rajakaruna et al. 2006). Therefore, recent research has focused on sustainable remediation techniques such as the use of biochar $(\mathrm{BC})$ to reduce metal toxicity in metal-enriched agricultural soils (Ahmad et al. 2014c; AlWabel et al. 2015; Herath et al. 2015). Biochar is carbon rich and is produced from organic substances under a pyrolysis process (Ahmad et al. 2014c). The addition of BC into soils improves plant growth (Jones et al. 2012) primarily by increasing nutrient retention (Zheng et al. 2013) and by improving microbial activities (Lehmann et al. 2011). In recent years, studies have highlighted $\mathrm{BC}$ as an effective soil amendment to immobilize heavy metals in soils (Ahmad et al. 2012; Ahmad et al. 2014a; Rajapaksha et al. 2015). Herath et al. (2015) documented that the addition of $\mathrm{BC}$ to serpentine soil immobilizes $\mathrm{Cr}$, Ni and $\mathrm{Mn}$ by reducing heavy metal toxicity in tomato plants. The presence of heavy metals in soils can decrease soil microbial activity, soil fertility, and crop yield (Ma et al. 2009). Previous studies have revealed that microbes can reduce heavy metal toxicity in metal-contaminated aqueous solutions (Quintelas et al. 2009; Arini et al. 2012). Furthermore, a Ni-resistant bacterium was used successfully to reduce Ni availability in serpentine soil (Ma et al. 2009). Metals cannot be degraded as in the case of hydrocarbon substances. However, their bioavailability can be influenced by changing their physical and chemical characterizations (Almaroai et al. 2014). For example, microorganisms can convert toxic heavy metals into non-toxic (i.e., less bioavailable) forms (Singh and Cameotra 2004), thereby reducing phytotoxicity.

A decline in soil quality is a major problem in agricultural areas adjacent to serpentine outcrops due to the presence of heavy metals (Vithanage et al. 2014). Soil enzymes provide means to identify soil quality; the application of $\mathrm{BC}$ as a soil amendment may have differential effects on soil enzyme activity (Awad et al. 2012). Paz-Ferreiro et al. (2012) reported that the addition of $\mathrm{BC}$ derived from sewage sludge increases dehydrogenase activity (DHA) while decreasing $\beta$ - glucosidase activity. In contrast, Wu et al. (2013) observed that the application of wheat straw biomass and $\mathrm{BC}$ showed no change in the soil dehydrogenase activity. However, the activity of $\beta$ glucosidase increased with increasing application rates of straw while it decreased with the application of BC.

The use of microorganisms in soil and water remediation is an emerging field (He and Yang 2007; Singh and Cameotra 2004) and only a few studies have assessed the performance of the fungal-bacterial co-inoculation $(\mathrm{FB})$ in soil remediation. The immobilization of toxic metals found in soil can be a function of physico-chemical characteristics of the medium, the availability of reactive sites of mineral surface, organic functional groups, or the microenvironments of the matrix of FB (Van Hullebusch et al. 2003; Seneviratne et al. 2015b). It has been previously reported that metal immobility in a FB is governed by several mechanisms, including mass transfer of metals, bio-sorption, and precipitation. The matrix of particular FB commonly consists of a variety of extracellular polymeric substances (EPS) such as cationic and anionic functional groups $\left(\mathrm{NH}_{3}{ }^{+}, \mathrm{COO}^{-}, \mathrm{HPO}_{4}^{-}\right.$, etc.), aromatic amino acids and polysaccharides, which lead to various physical as well as chemical interactions between metals and the surface of FB, thereby resulting in a strong retention or accumulation of toxic metals in the matrix (Van Hullebusch et al. 2003). Moreover, the surface area to volume ratio of FB is another key factor that can directly promote significant retention of metals in the co-inoculation matrix due to its large contact interface (Quintelas et al. 2009).

Studies conducted to date suggest that heavy metal immobilization is greater under co-inoculation than when using mono or mixed cultures of bacterial inoculations (Herath et al. 2014; Seneviratne et al. 2015b). Therefore, there is a potential for co-inoculation to be used in wastewater reactors for heavy metal remediation (Bestawy et al. 2013). A recent study demonstrated synergistic effects of FB for the enhancement of soil quality and the promotion of plant growth in the presence of heavy metals (Seneviratne et al. 2015a). However, to our knowledge, we have not found any studies assessing the joint effect of both co-inoculation and $\mathrm{BC}$ on the soil quality of a heavy-metal-rich soil. The present study investigated the combined effect of $\mathrm{BC}$ and co-inoculation of fungi and bacteria on the enzyme activity and heavy metal immobilization in naturally metal-rich serpentine soil.

\section{Materials and methods}

\subsection{Soil, amendments, and treatments}

Pre-characterized bulk surface samples of serpentine soils $(0$ $15 \mathrm{~cm}$ ) were randomly collected from Wasgamuwa (latitude $7^{\circ} 71^{\prime} 67^{\prime \prime} \mathrm{N}$ and longitude $80^{\circ} 93^{\prime} 33^{\prime \prime} \mathrm{E}$ ) (Vithanage et al. 2014), Sri Lanka for use in this study. Soils were mixed and homogenized into one homogeneous sample, air-dried, and mechanically sieved to a particle size of $<2 \mathrm{~mm}$ prior to the experiments. Two kinds of $\mathrm{BC}$ were used: $\mathrm{BC} 300$ was produced from Gliricidia sepium (Fabaceae) biomass pyrolysed at a constant temperature of $300{ }^{\circ} \mathrm{C}$ for $3 \mathrm{~h}$ using a muffle furnace (P300, Nabertherm, Germany), while BC700 was obtained directly from the bioenergy industry in Sri Lanka. Metal resistance bacteria were isolated from Wasgamuwa serpentine soil and combined with a garden soil fungus (Aspergillus niger) in the FB medium (Herath et al. 2014; Seneviratne et al. 2015a).

Untreated soil (control) and soil treated with three concentrations of BC amendment were used in this experiment. Soil 
amendments were prepared by mixing $250 \mathrm{~g}$ of soil and BC $(<2$-mm particle size) with a mass fraction of 1.0, 2.5, and $5.0 \%(w / w)$. The pot experiments were carried out with and without FB. Co-inoculation was diluted up to a 1:15 ratio with distilled deionized water and $15 \mathrm{ml}$ of that solution was added to each pot. Five tomato seeds (Lycopersicon esculentum L.) were sown in each pot and the plants were grown for 6 weeks in the greenhouse. Each treatment was performed in triplicate. The soil was irrigated with equal amounts of tap water $(30 \mathrm{ml})$ three times per week to maintain soil moisture at $70 \%$ of the water-holding capacity. The treatments consisted of a control soil without amendment $(\mathrm{S})$, soil with co-inoculation $(\mathrm{S}+\mathrm{FB})$, $300^{\circ} \mathrm{C}$ biochar $(\mathrm{BC} 300), 300^{\circ} \mathrm{C}$ biochar with co-inoculation (BC300+FB), $700^{\circ} \mathrm{C}$ biochar $(\mathrm{BC} 700)$, and $700^{\circ} \mathrm{C}$ biochar with co-inoculation $(\mathrm{BC} 700+\mathrm{FB})$.

\subsection{Plant analysis}

Five weeks after germination, plants were harvested, washed with tap water, and rinsed with deionized water. The plants were then dried in an oven at $60^{\circ} \mathrm{C}$ for $48 \mathrm{~h}$ and the dry weight of each plant was measured after cooling in a desiccator. The total $\mathrm{Ni}, \mathrm{Mn}$, and $\mathrm{Cr}$ content in the plant tissue was determined using atomic absorption spectrophotometer (AAS; AASModel GBC 933 AA) after being digested with $5 \mathrm{ml}$ of concentrated $\mathrm{HNO}_{3}$ acid in a closed vessel temperature controlled microwave digester system (CEM MARS 6).

\subsection{Analyses of enzyme activity and geometric mean as a soil quality index}

The activity of the following enzymes was determined: dehydrogenase (Tabatabai 1994), plyphenol oxidase (Wang et al. 2013), and catalase (Jin et al. 2009). All assays were carried out in triplicate. The geometric mean (GMea) of the assayed enzyme activities was calculated for each sample using the following equation described by Paz-Ferreiro et al. (2013):

GMea $=(\text { Catalase } \times \text { Dehydrogenase } \times \text { Polyphenol oxidase })^{1 / 4}$

\subsection{Analysis of heavy metals}

The bioavailable fraction of metals in the soil was analyzed by $0.01 \mathrm{M} \mathrm{CaCl}_{2}$ and sequential extractions following the methods of Tessier et al. (1979) and Armienta et al. (1996).

\subsection{Statistical analysis}

All results are expressed as means. The difference between $\mathrm{BC} / \mathrm{FB}$-amended and non-amended soil was analyzed using a one-way analysis of variance (ANOVA). The mean separation was estimated using Duncan's Multiple Range Test $(P=$
0.05). All statistical analyses were carried out using a statistical software package (SAS 9.1).

\section{Results}

\subsection{Soil properties}

The influence of BC and FB amendments on changes in several soil physiochemical parameters including $\mathrm{pH}$, cationexchange capacity (CEC) and electrical conductivity (EC) of serpentine soils are summarized in Table 1 . The $\mathrm{pH}$ values of all the treatments were between 5.73 and 6.95 and none were significant at a $5 \%$ probability level. However, the results showed a slight increase in $\mathrm{pH}$ with the $\mathrm{BC}$ preparation temperature (i.e., pyrolysis temperature) and concentration. The addition of $\mathrm{BC}$ significantly increased the soil CEC and this increase depended on the $\mathrm{BC}$ production temperature and application rates. The $5 \% \mathrm{BC} 700$ treatment showed the highest $\mathrm{CEC}$ value compared to the other treatments while soil amended with FB showed a reduction in CEC. The maximum $\mathrm{EC}$ value was at a $5 \% \mathrm{BC} 700+\mathrm{FB}$ treatment with the application of FB slightly increasing soil EC.

\subsection{Greenhouse experiments}

Generally, all the treatments contributed to an increase in plant height and dry weight compared to the control (S). The addition of $\mathrm{BC}$ and microorganisms (FB) enhanced the growth of tomato plants. Ten days after germination, signs of metal toxicity and nutrient deficiency (leaf chlorosis, necrosis, and growth retardation) were observed in the $\mathrm{S}$, with plants unable to

Table 1 Effects of BC and FB amendments on $\mathrm{pH}, \mathrm{CEC}$ and $\mathrm{EC}$ in serpentine soil

\begin{tabular}{lccl}
\hline Treatments & $\mathrm{pH}$ & $\mathrm{CEC}(\mathrm{cmol}+\mathrm{kg})$ & $\mathrm{EC}(\mu \mathrm{S} / \mathrm{cm})$ \\
\hline $\mathrm{S}$ & $5.75 \pm 2.62$ & $3.74 \pm 0.95$ & $349.00 \pm 59.60$ \\
$\mathrm{~S}+\mathrm{FB}$ & $5.73 \pm 1.83$ & $3.74 \pm 0.48$ & $310.00 \pm 65.71$ \\
$1 \%$ BC300 & $5.87 \pm 1.44$ & $4.34 \pm 1.56$ & $258.50 \pm 25.62$ \\
$1 \%$ BC300+FB & $5.82 \pm 2.95$ & $4.32 \pm 1.65$ & $293.40 \pm 93.13$ \\
$1 \%$ BC700 & $5.92 \pm 3.51$ & $6.34 \pm 2.24$ & $304.00 \pm 62.35$ \\
$1 \%$ BC700+FB & $5.84 \pm 1.62$ & $6.25 \pm 2.39$ & $427.00 \pm 81.96$ \\
$2.5 \%$ BC300 & $5.99 \pm 3.43$ & $5.62 \pm 1.38$ & $678.00 \pm 119.07$ \\
$2.5 \%$ BC300+FB & $5.97 \pm 2.44$ & $5.28 \pm 2.31$ & $447.00 \pm 117.28$ \\
$2.5 \%$ BC700 & $6.53 \pm 3.16$ & $10.07 \pm 3.23$ & $140.90 \pm 44.74$ \\
$2.5 \%$ BC700+FB & $6.29 \pm 3.57$ & $9.46 \pm 2.32$ & $368.00 \pm 119.25$ \\
$5 \%$ BC300 & $6.14 \pm 2.58$ & $7.88 \pm 2.22$ & $428.00 \pm 221.66$ \\
$5 \%$ BC300+FB & $5.98 \pm 3.15$ & $7.46 \pm 3.31$ & $787.00 \pm 328.23$ \\
$5 \%$ BC700 & $6.95 \pm 3.26$ & $14.98 \pm 4.57$ & $314.00 \pm 126.34$ \\
$5 \%$ BC700+FB & $6.74 \pm 2.23$ & $14.16 \pm 4.61$ & $842.00 \pm 388.45$ \\
\hline
\end{tabular}


survive after 40 days. However, $2.5 \%$ BC700 and $5 \%$ BC700+FB amended soil showed the highest shoot length; it was 2.2-fold greater compared to that of the $\mathrm{S}$. The highest dry weight was observed at $5 \% \mathrm{BC} 700$ and $5 \% \mathrm{BC} 700+\mathrm{FB}$; they were 6.5- and 6.8-fold higher compared to that of the $\mathrm{S}$ (Fig. 1).

Fig. 1 The a height and $\mathbf{b}$ dry weight of plants grown in BCand FB-amended and nonamended soil. Within a single graph, bars topped by the same letter are not significantly different $(P<0.05)$. Error bars represent standard errors of the means $(n=3)$

\subsection{Effects of BC and FB on heavy metal uptake in tomato plants}

Bioaccumulation of $\mathrm{Ni}$ and $\mathrm{Mn}$ in tomato plants grown in $\mathrm{BC}$ and FB-amended and non-amended serpentine soils are depicted in Table 2. All BC applications significantly reduced
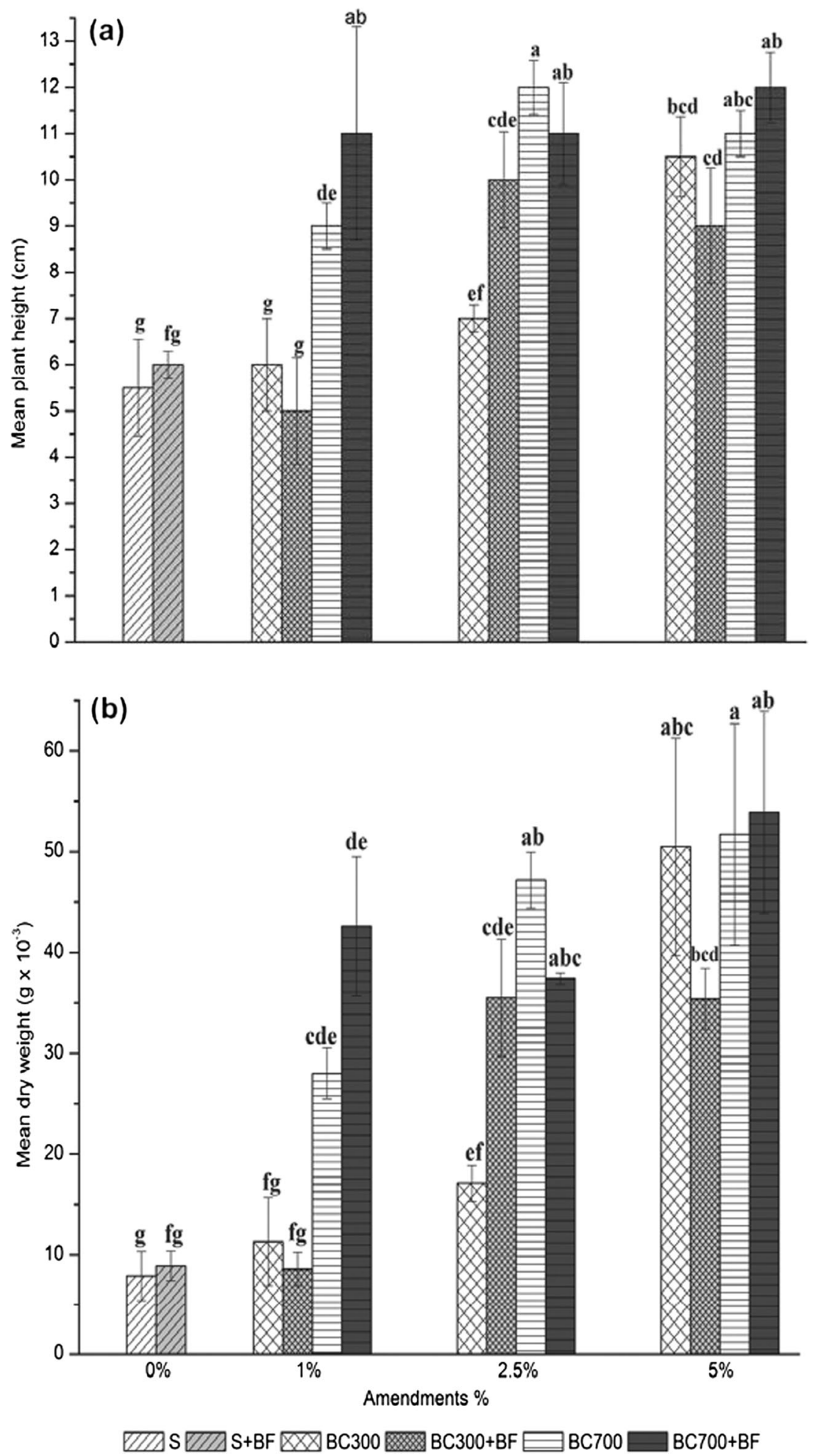
Table 2 Concentrations of $\mathrm{Ni}$ and $\mathrm{Mn}$ in tomato plants grown in $\mathrm{BC}$ and FB- amended serpentine soil

\begin{tabular}{lll}
\hline Treatments & \multicolumn{2}{l}{ Accumulated concentrations (ppb) } \\
\cline { 2 - 3 } & $\mathrm{Ni}$ & $\mathrm{Mn}$ \\
\hline $\mathrm{S}$ & $27.0 \pm 3.0$ & $23.0 \pm 5.0$ \\
$\mathrm{~S}+\mathrm{FB}$ & $25.0 \pm 3.0$ & $19.0 \pm 3.0$ \\
$1 \% \mathrm{BC} 300$ & $17.0 \pm 4.0$ & $14.0 \pm 2.0$ \\
$1 \% \mathrm{BC} 300+\mathrm{FB}$ & $18.0 \pm 2.0$ & $16.0 \pm 4.0$ \\
$1 \% \mathrm{BC} 700$ & $13.0 \pm 3.0$ & $10.0 \pm 6.0$ \\
$1 \% \mathrm{BC} 700+\mathrm{FB}$ & $16.0 \pm 3.0$ & $11.0 \pm 3.0$ \\
$2.5 \% \mathrm{BC} 300$ & $15.0 \pm 4.0$ & $10.0 \pm 4.0$ \\
$2.5 \% \mathrm{BC} 300+\mathrm{FB}$ & $16.0 \pm 5.0$ & $12.0 \pm 4.0$ \\
$2.5 \% \mathrm{BC} 700$ & $09.0 \pm 1.0$ & $05.0 \pm 2.0$ \\
$2.5 \% \mathrm{BC} 700+\mathrm{FB}$ & $11.0 \pm 3.0$ & $08.0 \pm 1.0$ \\
$5 \% \mathrm{BC} 300$ & $12.0 \pm 2.0$ & $06.0 \pm 1.0$ \\
$5 \% \mathrm{BC} 300+\mathrm{FB}$ & $13.0 \pm 2.0$ & $08.0 \pm 2.0$ \\
$5 \% \mathrm{BC} 700$ & $02.0 \pm 1.0$ & $02.0 \pm 3.0$ \\
$5 \% \mathrm{BC} 700+\mathrm{FB}$ & $10.0 \pm 4.0$ & $05.0 \pm 3.0$ \\
\hline
\end{tabular}

the uptake and bioaccumulation of $\mathrm{Ni}$ and $\mathrm{Mn}$ in tomato plants irrespective of their application rates and the pyrolysing temperatures. The maximum accumulation of metals was found in the $\mathrm{S}$ soil. The minimum accumulation of metals occurred in tomato plants grown in $5 \% \mathrm{BC} 700$ treatment. As the concentration of BC700 increased (i.e., 1, 2.5, and $5 \%$ ), the bioavailable fraction of $\mathrm{Ni}$ and $\mathrm{Mn}$ was reduced from 52 to $93 \%$ and from 57 to $91 \%$, respectively. The addition of $\mathrm{BC}$ and $\mathrm{FB}$ resulted in a slight increase in the bioaccumulation of $\mathrm{Ni}$ and Mn content compared to the soils amended with BC only. Overall, the bioaccumulation of $\mathrm{Ni}$ and $\mathrm{Mn}$ in tomato plants grown in the $\mathrm{S}$ soil was 12- to 14-fold higher than in the tomato plants grown in $5 \%$ BC700-amended serpentine soil.

\subsection{Enzyme activity}

The highest dehydrogenase activity was measured in the $1 \%$ $\mathrm{BC} 700+\mathrm{FB}$ treatment and it was 3.4-fold greater compared to the $\mathrm{S}$. The lowest activity was in the $2.5 \% \mathrm{BC} 300$ treatment and it was $33 \%$ lower compared to the $\mathrm{S}$. The maximum polyphenol oxidase activity (POA) was measured in $\mathrm{S}+\mathrm{FB}$ (a $15 \%$ increase compared to the $\mathrm{S}$ ) and the minimum POA was measured in $1 \%$ BC700 (a $78 \%$ reduction compared to the S) treatment, which was significantly lower than in the rest of the treatments (Fig. 2). Catalase activity was significantly higher in $2.5 \% \mathrm{BC} 300$ and it was a $34 \%$ higher compared to the $\mathrm{S} ; 5 \% \mathrm{BC} 300$ showed the lowest activity, representing a $79 \%$ reduction, compared to the $\mathrm{S}$. All the enzymatic activities were increased with the application of FB into the $\mathrm{S}$ treatment. However, FB inoculation by itself significantly increased the soil DHA.
The highest GMea value was calculated for $\mathrm{S}+\mathrm{FB}$ and $1 \%$ $\mathrm{BC} 300+\mathrm{FB}$ treatments, showing about 33 and $31 \%$ increase compared to the S, respectively (Fig. 3). The lowest GMea values were observed in $5 \% \mathrm{BC} 700$ and $5 \% \mathrm{BC} 700+\mathrm{FB}$ soil and the decreases were about 46 and $34 \%$ compared to the $\mathrm{S}$, respectively.

\subsection{Bioavailability of heavy metals}

The $\mathrm{CaCl}_{2}$ extractable fraction of $\mathrm{Ni}, \mathrm{Mn}$, and $\mathrm{Cr}$ significantly decreased with the incorporation of $\mathrm{BC}$. The reduction of metal bioavailability increased significantly with the $\mathrm{BC}$ preparation temperature and its rate of application. The $5 \%$ BC700 application was the most effective treatment because the removal efficiencies for $\mathrm{Ni}, \mathrm{Mn}$, and $\mathrm{Cr}$ were 92,94 , and $100 \%$, respectively. With increasing $\mathrm{BC}$ concentrations of BC700 (i.e., 1, 2.5, and $5 \%$ ), bioavailable concentrations of $\mathrm{Ni}, \mathrm{Mn}$, and Cr decreased by $40-92,78-94$, and $38-100 \%$, respectively, compared to the $\mathrm{S}$.

\section{Discussion}

The major challenges plants face in serpentine environments are low essential nutrients, elevated concentrations of toxic heavy metals, low water availability, and a comparatively low $\mathrm{Ca} / \mathrm{Mg}$ ratio (Vithanage et al. 2014). Biochar is effective in changing the physical, chemical, and biological properties of soil (Zhang et al. 2013), thereby influencing metal toxicity in plants (Herath et al. 2015). We observed that the addition of $\mathrm{BC}$ increased the soil $\mathrm{pH}$, a condition favorable for reducing metal phytoavailability. The increase in $\mathrm{pH}$ is likely due to the alkaline nature of $\mathrm{BC}$. Basic cations, such as $\mathrm{Ca}, \mathrm{Mg}, \mathrm{K}$, and $\mathrm{Na}$, in biomass are transformed into oxides, hydroxies, and carbonates (e.g., ash) that can adhere to $\mathrm{BC}$ during the pyrolysis process (Houben et al. 2013b; Ahmad et al. 2014b). The dissolution of these alkaline substances increases the soil $\mathrm{pH}$ as well as the CEC, providing readily available nutrients for plant growth. Additionally, the increase in $\mathrm{pH}$ may also make heavy metals less bioavailable (Kashem and Singh 2001). Several authors have reported that the slight increase in $\mathrm{pH}$ due to BC may result from the decarboxylation of organic anions and ammonification in soil (Houben et al. 2013b). The increase of soil CEC in the presence of $\mathrm{BC}$ has also been noted in earlier studies (Karami et al. 2011; Houben et al. 2013b). The increase in available nutrient content with increasing concentrations of $\mathrm{BC}$ results from free bases, such as $\mathrm{K}^{+}, \mathrm{Ca}^{2+}$, and $\mathrm{Mg}^{2+}$, present in $\mathrm{BC}$. These free bases are released into the soil solution, thereby increasing the CEC of the soil, and providing readily available nutrients for plant growth (Houben et al. 2013a). The results showed lower values for $\mathrm{pH}$ and $\mathrm{CEC}$ for all the treatments of $\mathrm{BC}+\mathrm{FB}$ than for the treatments of $\mathrm{BC}$ without $\mathrm{FB}$. This could be due to the 
Fig. 2 Enzyme activities: a polyphenol oxidase, $\mathbf{b}$ catalase, $\mathbf{c}$ dehydrogenase in soil with different treatments. Within a single graph, bars topped by the same letter are not significantly different $(P<0.05)$. Error bars represent standard errors of the means $(n=3)$
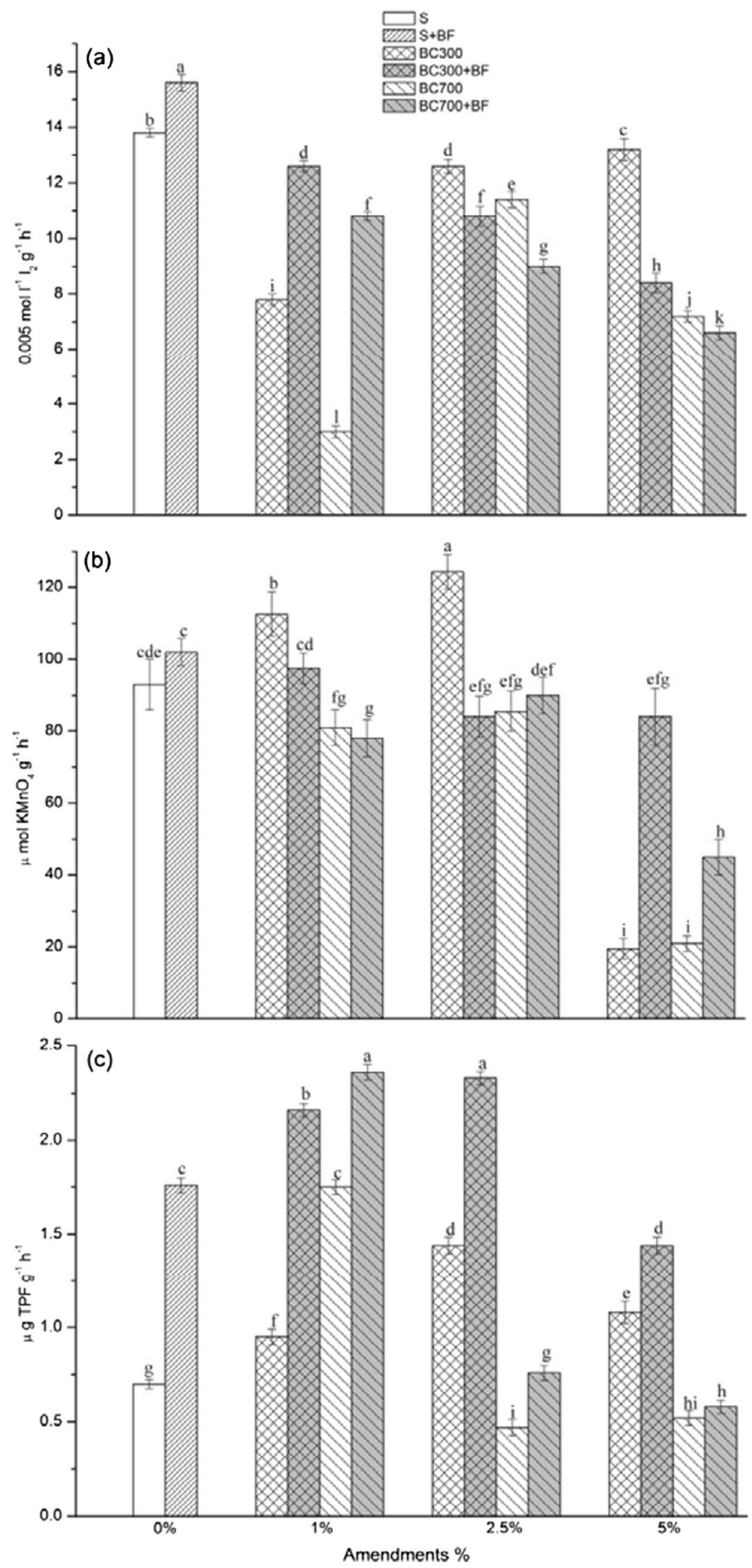
Fig. 3 The variation of GMea of enzyme activities in BC- and FBamended and non-amended soil. Within a single graph, bars topped by the same letter are not significantly different $(P<0.05)$ Error bars represent standard errors of the means $(n=3)$

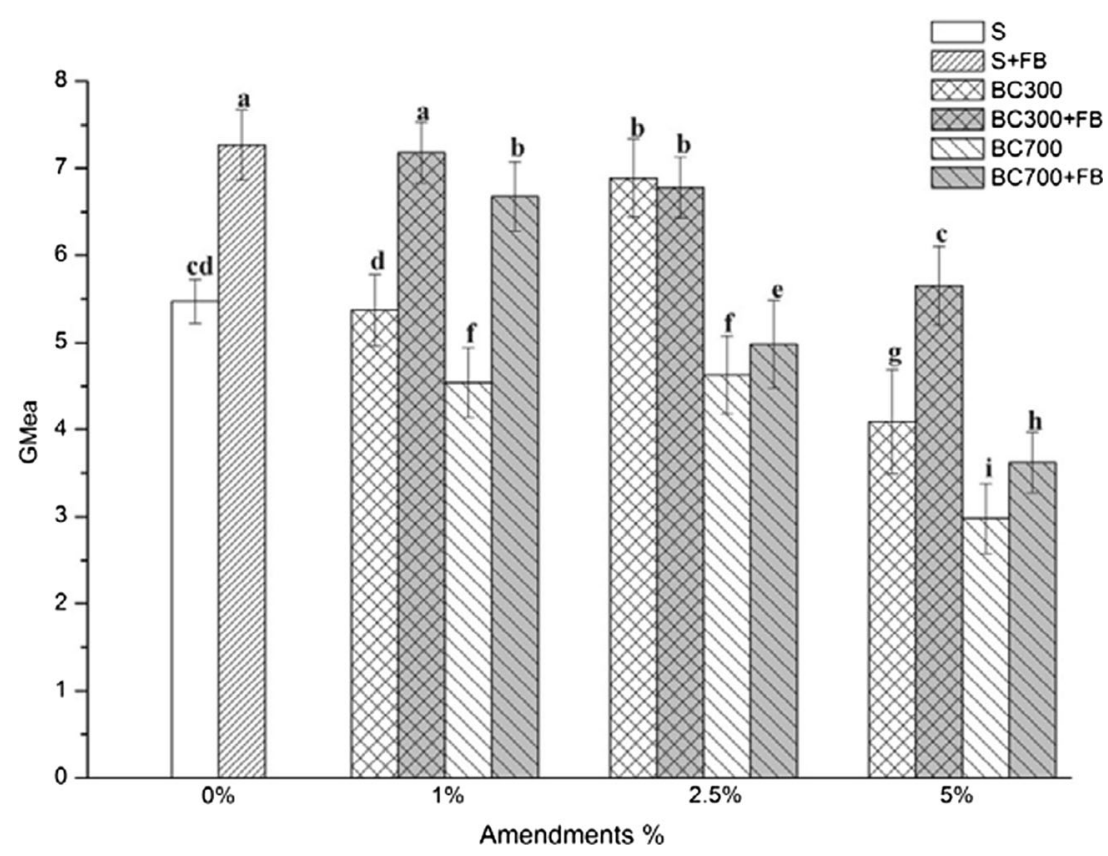

acidification of soil by the rhizospheric microorganisms (Smith and Read 1996; Qureshi et al. 2004). Soil EC increased with the application of FB in the BC amended soil. This may be the result of the dissolution of many salts due to the activity of FB.

The reduction in the accumulation of heavy metals in plants with different $\mathrm{BC}$ application rates and different pyrolysing temperatures is likely due to the immobilization of $\mathrm{Ni}$ and $\mathrm{Mn}$ in serpentine soil. Biochar can reduce metal solubility by raising the soil $\mathrm{pH}$ and through retention on cation exchange (CEC) sites (Lucchini et al. 2014). An increase in soil $\mathrm{pH}$ from the $\mathrm{BC}$ amendment may lead to decreased mobilization of heavy metal and ion precipitation. Because there are many functional groups (e.g., carboxylic, alcohol, and hydroxyl groups) on the surface of $\mathrm{BC}$, it is easy to form complexes with heavy metals and these groups (Jiang et al. 2012). The capacity to retain the metals in the $\mathrm{BC}$ mesopores could be increased with $\mathrm{BC}$ application rates and their pyrolysing temperatures. Therefore, the reduction of heavy metals in the presence of BC may improve essential nutrient uptake in plants, resulting in high biomass production. Our analysis suggests that the higher biomass production in the presence of a $5 \%$ BC700 application was accompanied by an enhancement in soil fertility as well as a reduction in the uptake of toxic metal ions in plants.

Soil enzymes play a fundamental role in organic matter decomposition and nutrient cycling. Our results suggest that the addition of FB into serpentine soil increases soil enzymatic activities. On the other hand, the enzymatic activities of BCamended soil generally depend on the sorption of enzymes or substrate into the porous structures of the $\mathrm{BC}$ (Lammirato et al. 2011). All the physio-chemical properties of BC mainly depend on the pyrolyzing temperature and the development of pores in $\mathrm{BC}$, which are both enhanced by increasing temperatures (Al-Wabel et al. 2013; Rajapaksha et al. 2014). Higher soil POA in an S+FB treatment may be due to the increased activity of fungi and bacteria. Compared to the $\mathrm{S}$, all the $\mathrm{BC}$ and $\mathrm{BC}+\mathrm{FB}$-amended soil showed a reduction of POA. This may be due to the sorption behavior of BC. Soil dehydogenase is an intracellular enzyme and its activity is considered a basic index for determining soil microbial activities (Demisie et al. 2014). Our results suggest that the DHA was higher in FBamended soil. However, increasing both the amended percentage and pyrolytic temperature reduced soil DHA.

Soil quality is important to sustain plant and animal productivity, maintain or enhance water and air quality, and support human health and habitation (Doran and Zeiss 2000). The geometric mean of enzyme activities has proven to be a good index for estimating soil quality and it can be used as an early sign of change in soil quality (Paz-Ferreiro et al. 2012). In our study, the highest GMea value was recorded in $\mathrm{S}+\mathrm{FB}$ and $1 \%$ BC300+FB treatments (Fig. 3). The lowest GMea values (2.98) were in $5 \% \mathrm{BC}$-amended soil, suggesting that the application of high doses of $\mathrm{BC}$ is harmful for soil microorganisms or soil enzymes dispersed in the pores of BC. In other words, the application of high doses of BC results in a decrease in soil quality. Our results showed a significant decrease in the bioavailable metal concentrations with an increase in $\mathrm{BC}$ amendment and the application of $\mathrm{BC}$ under high pyrolysing temperatures. Overall, the results demonstrated that in terms of Gmea, $1 \% \mathrm{BC}$ amendment is the best application rate in improving 
soil quality and that the $5 \% \mathrm{BC}$ application rate enhances soil quality by significantly immobilizing toxic metals. The present study also suggested that the $2.5 \% \mathrm{BC}$ application rate simultaneously maintains the quality of serpentine soil with regard to both physiochemical and biological parameters tested in this study. Furthermore, Ni showed the highest $\mathrm{CaCl}_{2}$ extractability under $\mathrm{BC}$ amended treatments. Hence, the bioavailability of $\mathrm{Ni}$, $\mathrm{Mn}$ and $\mathrm{Cr}$ in both $\mathrm{BC}$-amended and non-amended serpentine soil was in the order of $\mathrm{Ni}>\mathrm{Mn}>\mathrm{Cr}$.

\section{Conclusions}

Biochar (BC) and fungal-bacterial (FB) co-inoculation as soil amendments for effective remediation and soil quality enhancement have attracted much interest. Our results suggest that $\mathrm{BC}$ has the potential to significantly affect the behavior of metals in soil by altering their solubility, availability, transport and spatial distribution. Furthermore, the application of $\mathrm{BC}$ to metal-contaminated soil has the potential to achieve in situ remediation by immobilizing metals, thereby reducing metal availability for plants. In addition, $\mathrm{BC}$ improves agronomic properties by increasing nutrient availability and microbial activity. By-products obtained from the bio energy industry were more effective in both the immobilization of metals and the increase in plant growth compared to $\mathrm{BC}$ produced at $300{ }^{\circ} \mathrm{C}$. Therefore, BC700 can be used to enhance the phytostabilization of metal-contaminated soils. Our results also showed that $\mathrm{FB}$ co-inoculation with $\mathrm{BC}$ increases overall soil enzymatic activity in metal-contaminated soil. Overall, our study suggested that in terms of both geometric enzyme activity and metal immobility, the $2.5 \% \mathrm{BC}$ application rate simultaneously maintains the quality of serpentine soil. Furthermore, these inoculants release essential nutrients into the rhizosphere assisting in plant growth. Additional fieldbased studies can shed light on the applicability of these findings to enhance the quality of metal-contaminated soils in Sri Lanka.

Acknowledgments Biochar production and characterization of this research was supported by the Basic Science Research Program, through the National Research Foundation of Korea (NRF), funded by the Ministry of Education, Science and Technology (project number: 2012R1A1B3001409) (100\%).

\section{References}

Ahmad M, Soo Lee S, Yang JE, Ro HM, Han Lee Y, Sik Ok Y (2012) Effects of soil dilution and amendments (mussel shell, cow bone, and biochar) on $\mathrm{Pb}$ availability and phytotoxicity in military shooting range soil. Ecotoxicol Environ Saf 79:225-231
Ahmad M, Lee SS, Lim JE, Lee SE, Cho JS, Moon DH, Hashimoto Y, Ok YS (2014a) Speciation and phytoavailability of lead and antimony in a small arms range soil amended with mussel shell, cow bone and biochar: EXAFS spectroscopy and chemical extractions. Chemosphere 95:433-441

Ahmad M, Moon DH, Vithanage M, Koutsospyros A, Lee SS, Yang JE, Lee SE, Jeon C, Ok YS (2014b) Production and use of biochar from buffalo-weed (Ambrosia trifida L.) for trichloroethylene removal from water. J Chem Technol Biotechnol 89(1):150-157

Ahmad M, Rajapaksha AU, LimJE ZM, Bolan N, Mohan D, Vithanage M, Lee SS, Ok YS (2014c) Biochar as a sorbent for contaminant management in soil and water: a review. Chemosphere 99:19-23

Almaroai YA, Usman ARA, Ahmad M, Moon DH, Cho JS, Joo YK, Jeon C, Lee SS, Ok YS (2014) Effects of biochar, cow bone, and eggshell on $\mathrm{Pb}$ availability to maize in contaminated soil irrigated with saline water. Environ Earth Sci 71(3):1289-1296

Al-Wabel MI, Al-Omran A, El-Naggar AH, NadeemM UAR (2013) Pyrolysis temperature induced changes in characteristics and chemical composition of biochar produced from conocarpus wastes. Bioresour Technol 131:374-379

Al-Wabel MI, Usman AR, El-Naggar AH, Aly AA, Ibrahim HM, Elmaghraby S, Al-Omran A (2015) Conocarpus biochar as a soil amendment for reducing heavy metal availability and uptake by maize plants. Saudi J Biol Sci 22:503-511

Arini A, Feurtet-Mazel A, MorinS M-BR, Coste M, Delmas F (2012) Remediation of a watershed contaminated by heavy metals: a 2-year field biomonitoring of periphytic biofilms. Sci Total Environ 425: 242-253

Armienta M, Rodríguez R, Ceniceros N, Juarez F, Cruz O (1996) Distribution, origin and fate of chromium in soils in Guanajuato, Mexico. Environ Pollut 91(3):391-397

Awad YM, Blagodatskaya E, Ok YS, Kuzyakov Y (2012) Effects of polyacrylamide, biopolymer, and biochar on decomposition of soil organic matter and plant residues as determined by $14 \mathrm{C}$ and enzyme activities. Eur J Soil Biol 48:1-10

Baugé S, Lavkulich L, Schreier H (2013) Serpentine affected soils and the formation of magnesium phosphates (struvite). Can J Soil Sci 93(2): $161-172$

Bestawy EE, Helmy S, Hussien H, Fahmy M, Amer R (2013) Bioremediation of heavy metal-contaminated effluent using optimized activated sludge bacteria. Appl Water Sci 3(1):181-192

Demisie W, Liu Z, Zhang M (2014) Effect of biochar on carbon fractions and enzyme activity of red soil. Catena 121:214-221

Doran JW, Zeiss MR (2000) Soil health and sustainability: managing the biotic component of soil quality. Appl Soil Ecol 15(1):3-11

Gall JE, Boyd RS, Rajakaruna N (2015) Transfer of heavy metals through terrestrial food webs: a review. Environ Monit Assess 87:201

He Z-L, Yang X-E (2007) Role of soil rhizobacteria in phytoremediation of heavy metal contaminated soils. J Zhejiang Univ Sci B 8(3):192207

Herath H, Rajapaksha AU, Vithanage M, Seneviratne G (2014) Developed fungal-bacterial biofilms as a novel tool for bioremoval of hexavelant chromium from wastewater. Chem Ecol 30:418-427

Herath I, Kumarathilaka P, Navaratne A, Rajakaruna N, Vithanage M (2015) Immobilization and phytotoxicity reduction of heavy metals in serpentine soil using biochar. J Soils Sediments 15(1):126-138

Houben D, Evrard L, Sonnet P (2013a) Beneficial effects of biochar application to contaminated soils on the bioavailability of $\mathrm{Cd}, \mathrm{Pb}$ and $\mathrm{Zn}$ and the biomass production of rapeseed (Brassica napus L.). Biomass Bioenergy 57:196-204

Houben D, Evrard L, Sonnet P (2013b) Mobility, bioavailability and pHdependent leaching of cadmium, zinc and lead in a contaminated soil amended with biochar. Chemosphere 92(11):1450-1457

Jiang T-Y, Jiang J, Xu R-K, Li Z (2012) Adsorption of Pb (II) on variable charge soils amended with rice-straw derived biochar. Chemosphere 89(3):249-256 
Jin K, Sleutel S, Buchan D, De Neve S, Cai D, Gabriëls D, Jin J (2009) Changes of soil enzyme activities under different tillage practices in the Chinese Loess Plateau. Soil Tillage Res 104(1):115-120

Jones D, Rousk J, Edwards-Jones G, DeLuca T, Murphy D (2012) Biochar-mediated changes in soil quality and plant growth in a three year field trial. Soil Biol Biochem 45:113-124

Karami N, Clemente R, Moreno-Jiménez E, Lepp NW, Beesley L (2011) Efficiency of green waste compost and biochar soil amendments for reducing lead and copper mobility and uptake to ryegrass. J Hazard Mater 191(1):41-48

Kashem M, Singh B (2001) Metal availability in contaminated soils: I. Effects of floodingand organic matter on changes in $\mathrm{Eh}, \mathrm{pH}$ and solubility of Cd, Ni andZn. Nutr Cycl Agroecosyst 61(3):247-255

Kayama M, Sasa K, Koike T (2002) Needle life span, photosynthetic rate and nutrient concentration of Picea glehnii, P. Jezoensis and P. Abies planted on serpentine soil in northern Japan. Tree Physiol 22(10): 707-716

Lammirato C, Miltner A, Kaestner M (2011) Effects of wood char and activated carbon on the hydrolysis of cellobiose by $\beta$-glucosidase from Aspergillus niger. Soil Biol Biochem 43(9):1936-1942

Lehmann J, Rillig MC, Thies J, Masiello CA, Hockaday WC, Crowley D (2011) Biochar effects on soil biota - a review. Soil Biol Biochem 43(9):1812-1836

Lucchini P, Quilliam RS, DeLuca TH, Vamerali T, Jones DL (2014) Does biochar application alter heavy metal dynamics in agricultural soil? Agric Ecosyst Environ 184:149-157

Ma Y, Rajkumar M, Freitas H (2009) Improvement of plant growth and nickel uptake by nickel resistant-plant-growth promoting bacteria. J Hazard Mater 166(2-3):1154-1161

Neilson S, Rajakaruna N (2015) Phytoremediation of agricultural soils: using plants to clean metal-contaminated arable land. In: Phytoremediation, Springer, 159-168

Paz-Ferreiro J, Gascó G, Gutiérrez B, Méndez A (2012) Soil biochemical activities and the geometric mean of enzyme activities after application of sewage sludge and sewage sludge biochar to soil. Biol Fert Soils 48(5):511-517

Paz-Ferreiro J, Lu H, Fu S, Méndez A, Gascó G (2013) Use of phytoremediation and biochar to remediate heavy metal polluted soils: a review. Solid Earth Discuss 5(2):2155-2179

Quintelas C, Rocha Z, Silva B, Fonseca B, Figueiredo H, Tavares T (2009) Removal of Cd (II), Cr (VI), Fe (III) and Ni (II) from aqueous solutions by an E. Coli biofilm supported on kaolin. Chem Eng J 149(1):319-324

Qureshi S, Richards BK, Steenhuis TS, McBride MB, Baveye P, Dousset $\mathrm{S}$ (2004) Microbial acidification and $\mathrm{pH}$ effects on trace element release from sewage sludge. Environ Pollut 132(1):61-71

Rajakaruna N, Tompkins KM, Pavicevic PG (2006) Phytoremediation: an affordable green technology for the clean-up of metalcontaminated sites in Sri Lanka. Ceylon J Sci 35:25-39

Rajapaksha AU, Vithanage M, Oze C, Bandara WMAT, Weerasooriya R (2012) Nickel and manganese release in serpentine soil from the ussangoda ultramafic complex, Sri Lanka. Geoderma 189-190:1-9
Rajapaksha AU, Vithanage M, Ok YS, Oze C (2013) Cr(VI) formation related to $\mathrm{Cr}$ (III)-muscovite and birnessite interactions in ultramafic environments. Environ Sci Technol 47(17):9722-9729

Rajapaksha AU, Vithanage M, Zhang M, Ahmad M, Mohan D, Chang SX, Ok YS (2014) Pyrolysis condition affected sulfamethazine sorption by tea waste biochars. Bioresour Technol 166:303-308

Rajapaksha A, Ahmad M, Vithanage M, Kim K-R, Chang J, Lee S, Ok Y (2015) The role of biochar, natural iron oxides, and nanomaterials as soil amendments for immobilizing metals in shooting range soil. Environ Geochem Hlth 1-12

Seneviratne M, Seneviratne G, Madawala HMSP, Iqbal M, Rajakaruna N, Bandara T, Vithanage M (2015a) A preliminary study of the role of bacterial-fungal co-inoculation on heavy metal phytotoxicity in serpentine soil. Aust J Bot 63:261-268

Seneviratne M, Vithanage M, Madawala HMSP, Seneviratne G (2015b) A novel microbial biofilm for bioremoval of nickel from aqueous media. Bioremediation 19:239-248

Singh P, Cameotra SS (2004) Enhancement of metal bioremediation by use of microbial surfactants. Biochem Biophys Res Commun 319(2):291-297

Smith SE, Read DJ (1996) Mycorrhizal symbiosis. Academic press

Susaya JP, Kim K-H, Asio VB, Chen Z-S, Navarrete I (2010) Quantifying nickel in soils and plants in an ultramafic area in Philippines. Environ Monit Assess 167(1-4):505-514

Tabatabai MA (1994) Soil enzymes. In: Bottomley PS, Angle JS, Weaver RW (eds) Methods of soil analysis: part 2-microbiological and biochemical properties. Soil Science Society of America, Madison, pp 775-833

Tessier A, Campbell PG, Bisson M (1979) Sequential extraction procedure for the speciation of particulate trace metals. Anal Chem 51(7): 844-851

Tica D, Udovic M, Lestan D (2011) Immobilization of potentially toxic metals using different soil amendments. Chemosphere 85(4):577583

Van Hullebusch ED, Zandvoort MH, Lens PN (2003) Metal immobilisation by biofilms: mechanisms and analytical tools. Rev Environ Sci Biotechnol 2:9-33

Vithanage M, Rajapaksha A, Oze C, Rajakaruna N, Dissanayake CB (2014) Metal release from serpentine soils in Sri Lanka. Environ Monit Assess 186(6):3415-3429

Wang Q, Xiao F, He T, Wang S (2013) Responses of labile soil organic carbon and enzyme activity in mineral soils to forest conversion in the subtropics. Ann For Sci 70:579-587

Wu F, Jia Z, Wang S, Chang SX, Startsev A (2013) Contrasting effects of wheat straw and its biochar on greenhouse gas emissions and enzyme activities in a chernozemic soil. Biol Fert Soil 49(5):555-565

Zhang X, Wang H, He L, Lu K, Sarmah A, Li J, Bolan NS, Pei J, Huang H (2013) Using biochar for remediation of soils contaminated with heavy metals and organic pollutants. Environ Sci Pollut Res 20(12): $8472-8483$

Zheng H, Wang Z, Deng X, Herbert S, Xing B (2013) Impacts of adding biochar on nitrogen retention and bioavailability in agricultural soil. Geoderma 206:32-39 